\title{
Identification of Coastal Vulnerability at The North Pagai Island of Mentawai Using Smartline Method
}

\author{
Herdiana Mutmainah dan Aprizon Putra \\ Research Institute of Coastal Resources and Vulnerability, Agency of Research and Human Resources, \\ Ministry of Marine Affairs and Fisheries \\ Email : herdianamute77@gmail.com
}

\begin{abstract}
Climate change and global warming have a negative impact on coastal, especially small islands. Abration and floods can be very danger and need response to minimize the disaster risks. A simple and practical method is needed to inform the location and type of coastal vulnerability and its risks along coastal segments. Smartline is a coastal management method that represents the geomorphology of coastal, hinterland and shoreline. The North Pagai is a small island, a part of the Mentawai Islands that located at the west offshore of Sumatra Island and one of the under developed areas in Indonesia. The island is surrounded by the Hindia Ocean and located on a subduction path of tectonic plate that prone to earthquakes and Tsunami. High rainfall, strong winds, the complexity of coastal morphology and also the majority of coastal residents and limited infrastructure make the problems more complicated. Tsunami in $2010(7.7 \mathrm{Mw})$ caused the change of shoreline getting worst on The East Coast of The North Pagai Island. This study aims to identify the coastal vulnerability using Smartline method. The research was conducted on April and September 2016. The result concludes that physical aspect shows Saumangaya and Matobe Village at high and also very high level of vulnerability hence Sikakap Village at very high level. The socio-economic aspect shows that The Sikakap Village is more advanced but contrary more vulnerable to disaster in terms of population density and complex activities. The North Pagai Island is a vulnerable island from physical and socio-economic aspects.
\end{abstract}

Keywords : Smartline, Coastal Vulnerability, The North Pagai Island.

\section{Introduction}

Awareness raising on climate change, global warming and tsunami are increasingly encouraged especially for people living in coastal areas and small islands. Global warming and climate change have an impact on sea level rise and high precipitation with storms that cause abration and flooding on flat and sloping beaches. Assessment of coastal vulnerability is a challenge because of the complexity of problems such as physical, environmental, social and administrative conditions in coastal areas (Small and Nicholls, 2003). A variety of methods were undertaken to identify and assess coastal vulnerability but are still not integrated. Coastal vulnerability is a coastal disaster-prone condition caused by interactions between beaches, ecosystems and humans towards physical processes that have negative impacts such as abrationon, intrusion, flooding, inundation and others (Linds and Muehe, 2011). Coastal vulnerability due to climate change affects the deterioration of coastal socio-economic and physical conditions, especially in the still-conventional areas (Dolan and Walker, 2004). Therefore a strategy to establish adaptive communities and capacities with coastal physical and socio-economic indicators that depend on institutional infrastructure and capacity (Adger et al., 2004) is needed. Climate change affects natural and human systems so that adaptation and mitigation of climate-causing factors (IPCC, 2001) is needed. Overall, coastal vulnerability is linked to coastal, ecosystem, and resident capacity to recover and adapt to these negative impacts (Linds and Muehe, 2011). 
Both the government and the population need a simple, fast and precise method of obtaining location information, types and values of coastal vulnerability so that disaster risk can be minimized. Sharples (2006) introduced a method of coastal management approach called Smartline to rapidly identify the physical and socio-economic conditions of a coastal region along the coastline. Smartline is a form of information that represents geomorphological classification of hinterland, coastal and coastal areas.

Population growth and population density on the coast are directly and indirectly one of the causes of coastal vulnerability. Abrationon, flooding, sea water intrusion and pollution often occur in densely populated coastal areas due to inhospitable activity (Linds and Muehe, 2011). The condition of small islands prone to floods, abrationon, earthquake and tsunami with limited infrastructure make this island very vulnerable. This study aims to identify coastal vulnerability in North Pagai Island using Smartline method. Figure 1 shows the history of the earthquake and tsunami in the western waters of Sumatra and Figure 2 is the research location on the East Coast of North Pagai Island.

\section{Method}

Research was conducted on April and September year 2016 at the East Coast of the North Pagai Island. Research method using on field survey and secondary data. All the data sources as written on Table 1 and analyse into numbers that shows the criterias of zoning area using Smartline method. Linds and Muehe (2011) made modification of Smartline methods from Sharples (2006) using spatial technical analysis by overlay the geospatial data based on gradation color of boundary shoreline in sequence. The research identify coastal physical and social economy aspect. The assessment of coastal physical aspect was using Coastal Vulnerabilty Index method, based on weighting or scoring on parameters of ranges of tides, the height of significant waves, changes of shoreline and the shoreline slope while area description describes about morphology, sand material and rocks formation. The aspect of social economy consists of population, occupation, fishery industry and distance of fresh water from shoreline. The coordinates of location are marked using GPS. The observation points are 22 locations. The points determination is using purposive sampling method. Some points on hamlets were representated the condition of villages at the East Coast of the North Pagai Island. Interviews with residents and local government are conducted to determine the location of research both physic and social economic information of coastal communities. The geospatial and oceanography data were ranked according to their class with gradation color for physical aspect and the informations or data of coastal communities for socio- economic aspect based on field survey and support secondary data.

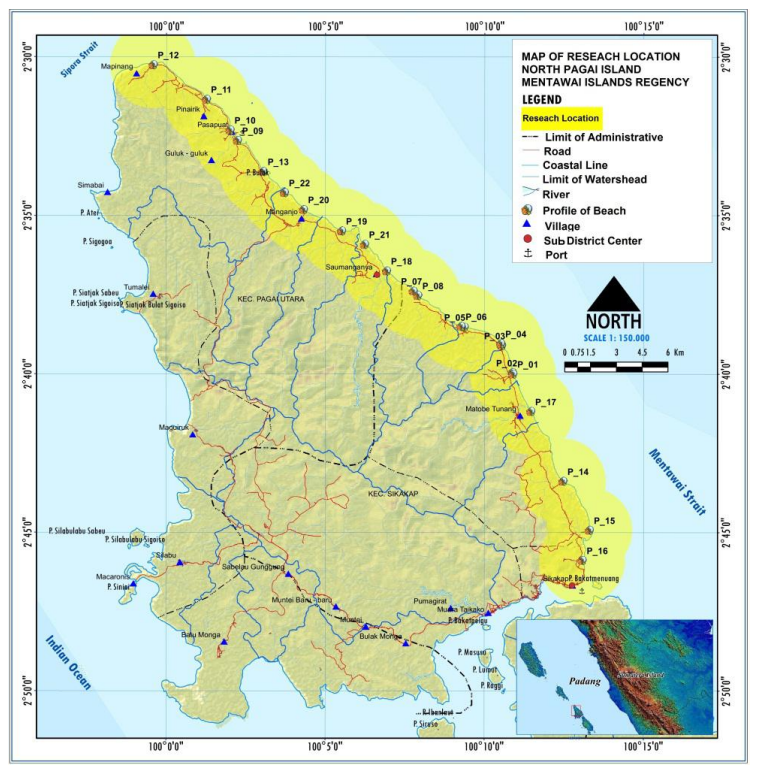

Figure 1. The Smartline's Observation Points at The East Coast of The North Pagai Island 
The parameters that used in Coastal Vulnerabilty Index as shown in this equation below.

$I K P=\sum\left(w_{1} \cdot x_{1}\right)+\left(w_{2} \cdot x_{2}\right)+\left(w_{3} \cdot x_{3}\right)+\left(w_{4} \cdot x_{4}\right)$

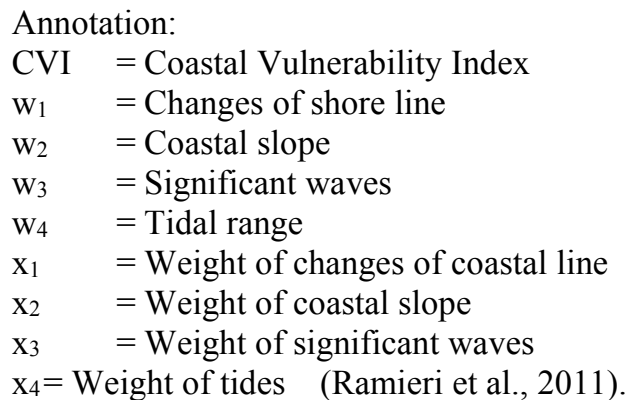

Analysis of shoreline's changes is explained in this equation below using ENVI V4.5 (ENVI Classic help, 2008).

$$
\begin{gathered}
\mathrm{V}=\frac{\mathrm{N}_{2}-\mathrm{N}_{1}}{\mathrm{~N}_{1}} \times 100 \% \quad \ldots \ldots \ldots \ldots \ldots \ldots \ldots \ldots \ldots \ldots \ldots \ldots \ldots \ldots \\
\text { Annotation: } \\
\mathrm{V}=\text { The rate of shoreline's change }(\%) ; \\
\mathrm{N} 1=\text { Area of first Year }(\mathrm{Ha}) ; \\
\mathrm{N} 2=\quad \text { Area of } \mathrm{n} \text { Year }(\mathrm{Ha}) .
\end{gathered}
$$

\section{Result and Discussion}

\section{Coastal Physical Aspect}

\section{Coastal Line dan Slope}

The length of shoreline digitation shows that East Coast at year 2006 is $\pm 53 \mathrm{~km}$ and $\pm 51,5 \mathrm{~km}$ at year 2016. Refers to Equation 2, the change of shoreline is $-4 \%$ and about $1,90 \mathrm{~km}$. The abration area along The East Coast is 102,19 Ha, while the accretion is 19,82 Ha in The Saumangaya Village. The Saumanganya Village is the longest shoreline that is $21.709 \mathrm{~km}$ whit slope is $1.1^{\circ}$ at certain segments. Some hamlets at The Saumangaya Village that bordered to Mentawai Strait i.e Manganjo, Pasapuat and East Saumangaya being abration while area that bordered with Sipora Strait being accretion, i.e Mapinang, Pinairik and Mabulau Buggei. The length of shoreline at The Matobe Village is $18.59 \mathrm{~km}$ with slope $1^{\circ}$ at certain segments of shoreline. Two hamlets at The Matobe Village that is The Mangaungau Hamlet and The Matobe Hamlet being abration while The Polaga Hamlet being accretion. The hamlets at The Sikakap Village, i.e Sibaibai and East Sikakap being abration. Abration dominates along the East Coast in different degrees. Abration caused by the topography that is flat, slightly slope and black mud sand. Furthermore, the Tsunami year 2010 (7.7 Mw) also affected great changes of shoreline at the East Coast. Table 1 and Table 2 below show the values of width and slope of shoreline and also the coastal vulnerabel status of abration and accretion. 
ISSN: 2580-4030 (Print) 2580-1775 (Online)

Vol 1, No. 2, (pp. 130-139), December, 2017

http://sjdgge.ppj.unp.ac.id

Table 1. The Slope of East Coast of The North Pagai Island.

\begin{tabular}{|c|c|c|c|c|c|c|}
\hline \multirow[t]{2}{*}{ Code } & \multirow[t]{2}{*}{ Hamlet } & \multicolumn{2}{|c|}{ Coordinates } & \multirow[t]{2}{*}{ Height (m) } & \multirow[t]{2}{*}{ Width (m) } & \multirow[t]{2}{*}{ Slope $(\alpha)^{\circ}$} \\
\hline & & ${ }^{\circ} \mathrm{SL}$ & ${ }^{\circ} \mathrm{EL}$ & & & \\
\hline P1 & Mangau-ngau & 2.6667 & 100.1814 & 17.4 & 36.0 & 0.5 \\
\hline $\mathbf{P 2}$ & Mangau-ngau & 2.6659 & 100.1812 & 20.3 & 36.0 & 0.5 \\
\hline P3 & Mangau-ngau & 2.6518 & 100.1755 & 22.8 & 43.2 & 0.5 \\
\hline P4 & Mangau-ngau & 2.6507 & 100.1751 & 25.0 & 46.0 & 0.5 \\
\hline P5 & Polaga & 2.6420 & 100.1359 & 18.5 & 57.0 & 0.3 \\
\hline P6 & Polaga & 2.6416 & 100.1543 & 21.5 & 52.0 & 0.4 \\
\hline P7 & Polaga & 2.6230 & 100.1292 & 38.0 & 49.0 & 0.7 \\
\hline P8 & Polaga & 2.6255 & 100.1316 & 33.3 & 48.0 & 0.6 \\
\hline P9 & Pasapuat & 2.5439 & 100.0372 & 32.8 & 21.3 & 1.0 \\
\hline P10 & Pasapuat & 2.5385 & 100.0332 & 25.0 & 18.5 & 0.9 \\
\hline P11 & Mabulau Buggei & 2.5138 & 100.0090 & 22.2 & 12.5 & 1.1 \\
\hline P12 & Mapinang & 2.5040 & 99.9878 & 17.2 & 19.2 & 0.7 \\
\hline P13 & Guluk-guluk & 2.5603 & 100.0506 & 19.3 & 9.1 & 1.1 \\
\hline P14 & Matobe Tunang & 2.7231 & 100.2077 & 29.2 & 49.2 & 0.5 \\
\hline P15 & Tapuraukat/East Sikakap & 2.7488 & 100.2215 & 30.1 & 43.21 & 0.6 \\
\hline P16 & Sibaibai & 2.7646 & 100.2178 & 21.1 & 20.1 & 0.8 \\
\hline P17 & Matobe Tunang & 2.6864 & 100.1908 & 19.2 & 49.2 & 0.4 \\
\hline P18 & East Saumanganya & 2.6125 & 100.1152 & 19.1 & 54.2 & 0.3 \\
\hline P19 & Manganjo & 2.5915 & 100.0917 & 20.2 & 41.2 & 0.5 \\
\hline P20 & Manganjo & 2.5803 & 100.0717 & 21.5 & 38.2 & 0.5 \\
\hline P21 & East Saumanganya & 2.5985 & 100.1036 & 21.3 & 19.2 & 0.8 \\
\hline $\mathbf{P 2 2}$ & Manganjo & 2.5714 & 100.0617 & 20.8 & 18.8 & 0.8 \\
\hline
\end{tabular}

Source : Field Survey, RICRV (2016)

Table 2. Segment Areas and Vulnerability Status of Shoreline at East Coast of The North Pagai Island

\begin{tabular}{|c|c|c|c|c|c|c|}
\hline \multirow[t]{2}{*}{ No } & \multirow[t]{2}{*}{ Hamlet } & \multicolumn{2}{|c|}{ Coordinates } & \multirow{2}{*}{$\begin{array}{l}\text { Area of } \\
\text { Coastal } \\
\text { Segments } \\
\left(\mathrm{m}^{2}\right)\end{array}$} & \multirow{2}{*}{$\begin{array}{l}\text { Average of } \\
\text { area's } \\
\text { changes } \\
\left(\mathbf{m}^{2} / \text { tahun }\right)\end{array}$} & \multirow{2}{*}{$\begin{array}{l}\text { Status of } \\
\text { Shoreline (2006- } \\
\text { 2016) }\end{array}$} \\
\hline & & ${ }^{\circ} \mathrm{SL}$ & ${ }^{\circ} \mathbf{E L}$ & & & \\
\hline 2 & Mangau-ngau & 2.6659 & 100.1812 & 36.48 & 3.6 & Abration \\
\hline 3 & Mangau-ngau & 2.6518 & 100.1755 & 43.82 & 4.4 & Abration \\
\hline 4 & Mangau-ngau & 2.6507 & 100.1751 & 46.49 & 4.6 & Abration \\
\hline 6 & Polaga & 2.6416 & 100.1543 & 0.19 & 0.01 & Accretion \\
\hline 7 & Polaga & 2.6230 & 100.1292 & 28.06 & 2.8 & Abration \\
\hline 8 & Polaga & 2.6255 & 100.1316 & 0.33 & 0.01 & Accretion \\
\hline 9 & Pasapuat & 2.5439 & 100.0372 & 4.96 & 0.5 & Accretion \\
\hline 10 & Pasapuat & 2.5385 & 100.0332 & 0.62 & 0.1 & Accretion \\
\hline 15 & Tapuraukat/East Sikakap & 2.7488 & 100.2215 & 56.66 & 5.7 & Abration \\
\hline 16 & Sibaibai & 2.7646 & 100.2178 & 21.18 & 2.1 & Abration \\
\hline 17 & Matobe Tunang & 2.6864 & 100.1908 & 69.88 & 7.0 & Abration \\
\hline 18 & East Saumanganya & 2.6125 & 100.1152 & 84.07 & 8.4 & Abration \\
\hline 19 & Manganjo & 2.5915 & 100.0917 & 97.75 & 9.8 & Abration \\
\hline 20 & Manganjo & 2.5803 & 100.0717 & 17.97 & 1.8 & Accretion \\
\hline 21 & East Saumanganya & 2.5985 & 100.1036 & 85.03 & 8.5 & Abration \\
\hline 22 & Manganjo & 2.5714 & 100.0617 & 8.87 & 0.9 & Accretion \\
\hline
\end{tabular}

Source : Landsat 7+ETM Imagery Map Year 2006 and OLI 8 Imagery Map Year 2016.

\section{Tidal Waves and Significant Waves}

The tidal range along East Coast, between $1.2 \mathrm{~m}$ at southern, that covers Sibaibai and Sikakap until northern island that is Mapinang, Saumangaya at $1.697 \mathrm{~m}$ (CMCMR, 2015 and RICRV, 2016). The average 
height of significant waves at Sibaibai to Matobe Tunang about $0-0.4 \mathrm{~m}$; Matobe Tunang to Saumangaya about $0.4-1.2 \mathrm{~m}$; while at Pinairik to Mapinang (northern North Pagai Island) over than $0.72 \mathrm{~m}$ (CMCMR, 2015 and RICRV, 2016). Furthermore, it is shown at Fig 2.

The result analysis of CVI at East Coast of North Pagai Island as shown at Table 3. The East Coast is categorized in two vulnerabel area that is high vulnerability at southern to middle coast with CVI $3.2-3.5$ and very high vulnerability at northern coast with CVI 4.2.

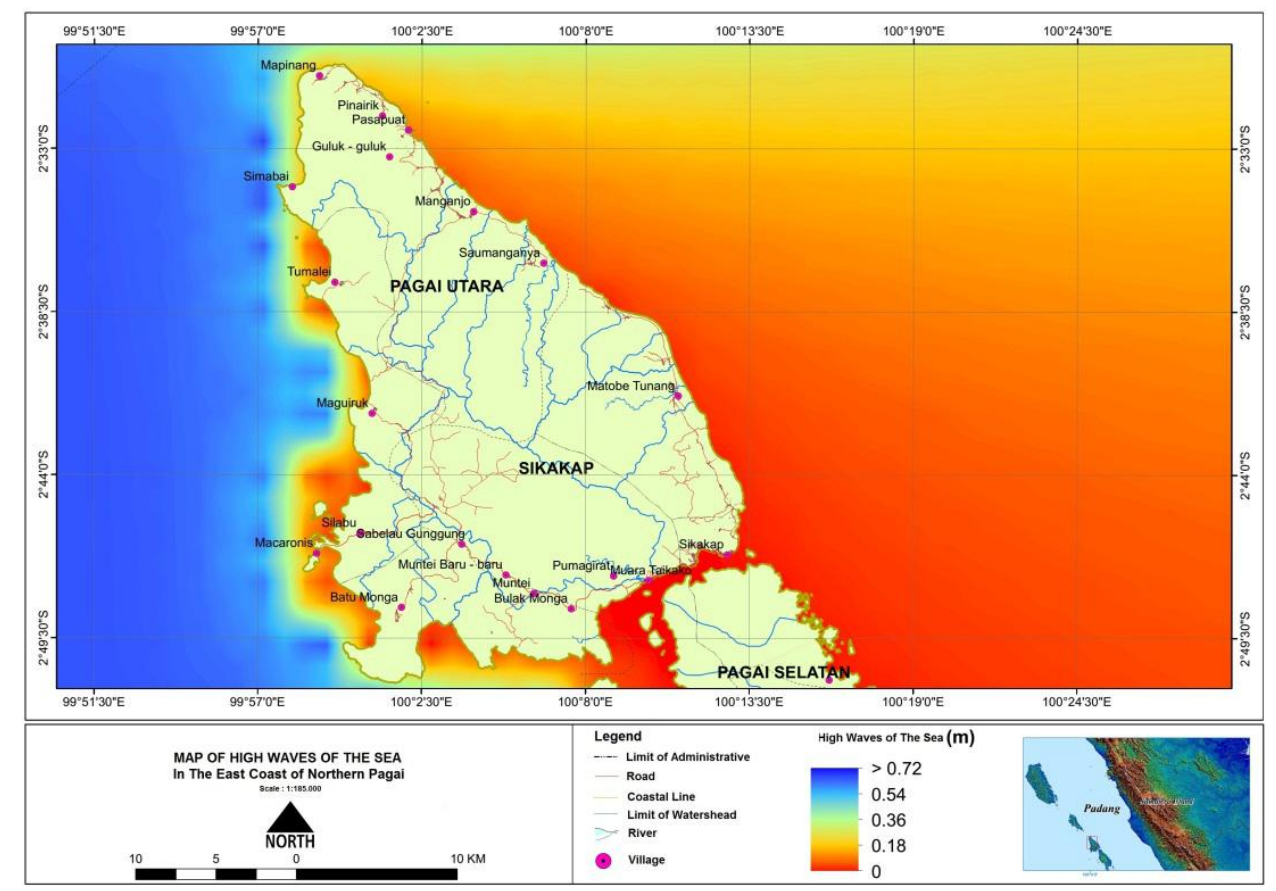

Figure 2. Map of Significant Waves around The North Pagai Island.

Table 3. Analysis of Coastal Vulnerability Index at The East Coast of The North Pagai Island

\begin{tabular}{|l|l|l|l|l|l|l|l|l|l|l|l|l|}
\hline \multirow{2}{*}{ No } & \multicolumn{2}{|l}{ Coordinates } & $\begin{array}{l}\text { Coast } \\
\text { line }\end{array}$ & $\begin{array}{l}\text { Coastal } \\
\text { Slope }\end{array}$ & Wave & Tides & $\begin{array}{l}\boldsymbol{W}_{\boldsymbol{*}}^{*} \\
\boldsymbol{X}^{*}\end{array}$ & $\begin{array}{l}\boldsymbol{W}^{*} \\
\boldsymbol{X}^{*}\end{array}$ & $\begin{array}{l}\boldsymbol{W}^{*} \\
\boldsymbol{X}^{*}\end{array}$ & $\begin{array}{l}\boldsymbol{W}^{*} \\
\boldsymbol{X}^{*}\end{array}$ & $\mathbf{C V I}$ & Ket. \\
\hline $\mathbf{1}$ & 2.6667 & 100.1814 & 5 & 5 & 3 & 3 & 1.25 & 1.75 & 0.87 & 0.33 & 4.2 & Very High \\
\hline $\mathbf{2}$ & 2.6659 & 100.1812 & 5 & 5 & 3 & 3 & 1.25 & 1.75 & 0.87 & 0.33 & 4.2 & Very High \\
\hline $\mathbf{3}$ & 2.6518 & 100.1755 & 5 & 5 & 3 & 3 & 1.25 & 1.75 & 0.87 & 0.33 & 4.2 & Very High \\
\hline $\mathbf{4}$ & 2.6507 & 100.1751 & 5 & 5 & 3 & 3 & 1.25 & 1.75 & 0.87 & 0.33 & 4.2 & Very High \\
\hline $\mathbf{5}$ & 2.6420 & 100.1359 & 1 & 5 & 3 & 3 & 0.25 & 1.75 & 0.87 & 0.33 & 3.2 & High \\
\hline $\mathbf{6}$ & 2.6416 & 100.1543 & 1 & 5 & 3 & 3 & 0.25 & 1.75 & 0.87 & 0.33 & 3.2 & High \\
\hline $\mathbf{7}$ & 2.6230 & 100.1292 & 5 & 5 & 3 & 3 & 1.25 & 1.75 & 0.87 & 0.33 & 4.2 & Very High \\
\hline $\mathbf{8}$ & 2.6255 & 100.1316 & 1 & 5 & 3 & 3 & 0.25 & 1.75 & 0.87 & 0.33 & 3.2 & High \\
\hline $\mathbf{9}$ & 2.5439 & 100.0372 & 1 & 5 & 3 & 3 & 0.25 & 1.75 & 0.87 & 0.33 & 3.2 & High \\
\hline $\mathbf{1 0}$ & 2.5385 & 100.0332 & 1 & 5 & 3 & 3 & 0.25 & 1.75 & 0.87 & 0.33 & 3.2 & High \\
\hline $\mathbf{1 1}$ & 2.5138 & 100.0090 & 1 & 5 & 3 & 3 & 0.25 & 1.75 & 0.87 & 0.33 & 3.2 & High \\
\hline $\mathbf{1 2}$ & 2.5040 & 99.9878 & 5 & 5 & 3 & 3 & 1.25 & 1.75 & 0.87 & 0.33 & 4.2 & Very High \\
\hline $\mathbf{1 3}$ & 2.5603 & 100.0506 & 1 & 5 & 3 & 3 & 0.25 & 1.75 & 0.87 & 0.33 & 3.2 & High \\
\hline $\mathbf{1 4}$ & 2.7231 & 100.2077 & 5 & 5 & 3 & 3 & 1.25 & 1.75 & 0.87 & 0.33 & 4.2 & Very High \\
\hline $\mathbf{1 5}$ & 2.7488 & 100.2215 & 5 & 5 & 3 & 3 & 1.25 & 1.75 & 0.87 & 0.33 & 4.2 & Very High \\
\hline $\mathbf{1 6}$ & 2.7646 & 100.2178 & 5 & 5 & 3 & 3 & 1.25 & 1.75 & 0.87 & 0.33 & 4.2 & Very High \\
\hline $\mathbf{1 7}$ & 2.6864 & 100.1908 & 5 & 5 & 3 & 3 & 1.25 & 1.75 & 0.87 & 0.33 & 4.2 & Very High \\
\hline $\mathbf{1 8}$ & 2.6125 & 100.1152 & 5 & 5 & 3 & 3 & 1.25 & 1.75 & 0.87 & 0.33 & 4.2 & Very High \\
\hline $\mathbf{2 0}$ & 2.5915 & 100.0917 & 2 & 5 & 3 & 3 & 0.50 & 1.75 & 0.87 & 0.33 & 3.5 & High \\
\hline $\mathbf{2 1}$ & 2.5803 & 100.0717 & 5 & 5 & 3 & 3 & 1.25 & 1.75 & 0.87 & 0.33 & 4.2 & Very High \\
\hline $\mathbf{2 2}$ & 2.5985 & 100.1036 & 1 & 5 & 3 & 3 & 0.25 & 1.75 & 0.87 & 0.33 & 3.2 & High \\
\hline
\end{tabular}

Source : Analysis Result (RICRV, 2016) 
Sand Material

The sand at northern of the East Coast i.e Pinairik, Pasapuat until Manganjo, Saumangaya are dominated by reef and white sandy; black or grey sandy beach are spread from middle Saumanganya to south Matobe Tunang; while mud sand or estuaria generally are spread at southern island with mangrove combination are found in Matobe Tunang, East Sikakap and Sibaibai.

\section{Coastal Morphology}

The morphology of the East Coast consists of 3 (three) forms i.e sandy rock that spread at northern island covers Mapinang Hamlet (Saumanganya Village); slopes lightly zone or flat dominated on East Sikakap Hamlet and Sibaibai Hamlet (Sikakap Village), while estuary zone covers the Matobe Tunang Hamlet (Matobe Village) as shown at Fig. 3.

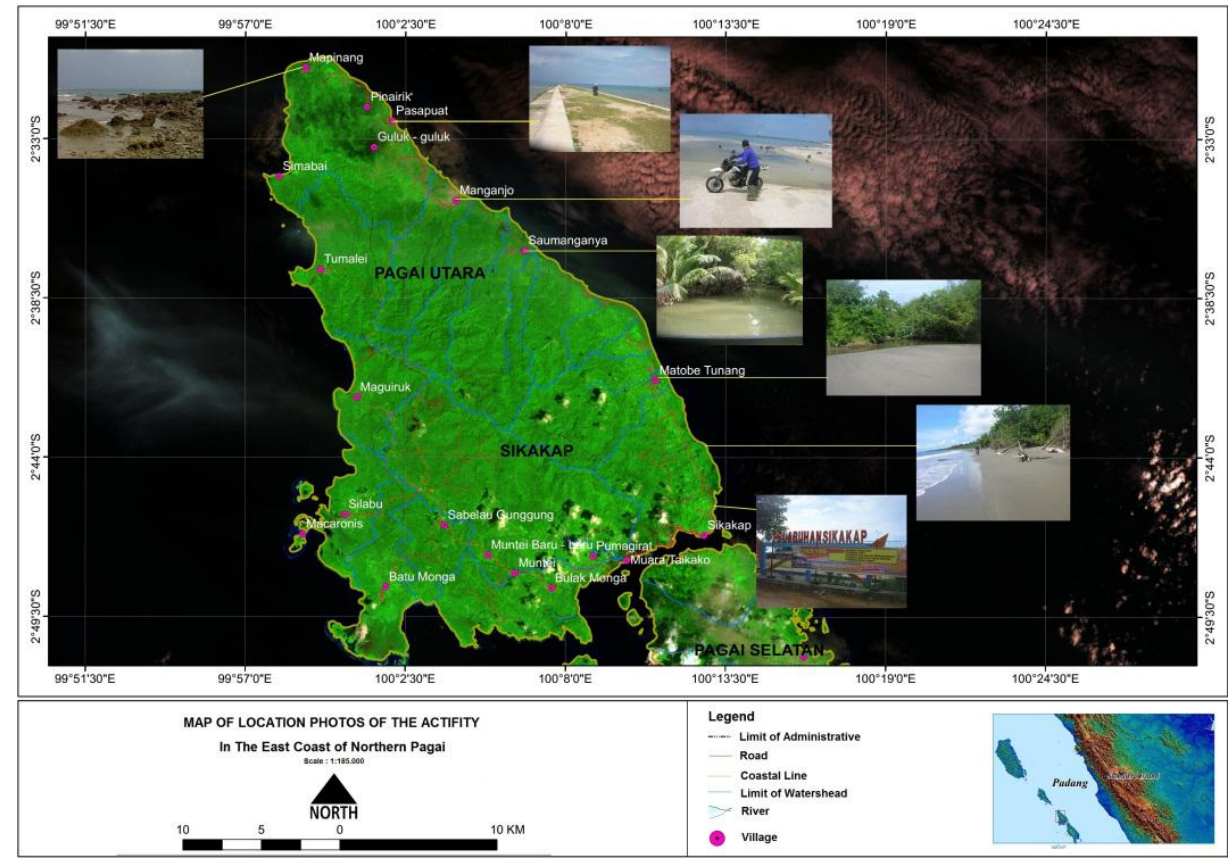

Figure 3. Morphology of The East Coast of The North Pagai Island.

\section{Rocks Formation}

Based on geological conditions, refers to the geological map of Pagai and Sipora sheets year 1990 (Budhitrisna and Mangga, 1990) shows that the coastal area of the East Coast at the North Pagai island consists of 6 types of rocks i.e alluvium rock with clay, gravel and crust type; Coral limestone; Rock of simatobat formation with reef rock type; Maonai formation with sandstone rock type; and unexposed rocks with numulit rock type. Level of coastal vulnerability based on CVI or coastal physical aspect were mapped using Smartline as shown on Fig 4. 


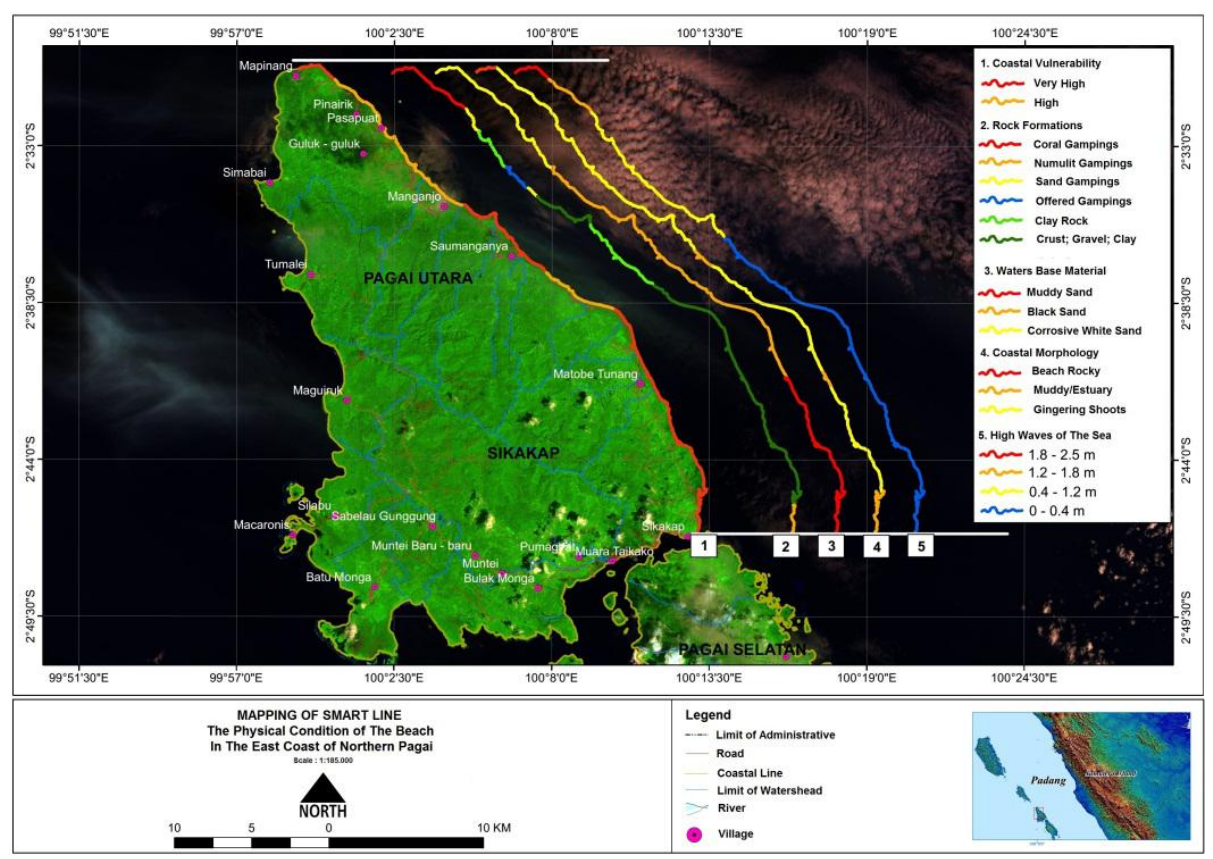

Figure 4. Smartline Map for Coastal Physical Aspect

\section{Socio-Economic Aspect}

The Sikakap Village (Sibaibai Hamlet and East Sikakap Hamlet)

The locations of residents in the southern East Coast of North Pagai Island are located in Sikakap Village, they are Sibaibai Hamlet and East Sikakap Hamlet. Based on field surveys, the settlement on site is about $10 \mathrm{~m}$ from the shoreline with a total population of 1,699 inhabitants (SCB, 2015). The distance of fresh water's sources for consumption is about 10 to $30 \mathrm{~m}$ from shoreline. The occupation of the local residents are fisherman, farmers, cattleman, local government employees and trades. The fishery business become their livelihood in different kind i.e the traditional and modern capture, the salted processing and also the shore and freshwater fish cultivation. This village is the most densely populated area in the North Pagai Island. Fisheries business is indicated by the existence of fishermen's cooperative and individual fishery business from some residents. Fishing business in this village is prioritizing commodities of lobster, sea cucumbers, grouper, fish cultivation, rental of fishing vessels and fish cages.

\section{The Saumangaya Village (Mapinang Hamlet, Pinairik Hamlet and Pasapuat Hamlet)}

The northern part of the East Coast that is Saumangaya Village actually has 7 (seven) hamlets, but due to limit of time and surveyors/persons, the social economy survey only can be done on 3 (three) hamlets i.e Mapinang Hamlet, Pinairik Hamlet and Pasapuat Hamlet. The population of Mapinang Hamlet is 201 people, Pinairik Hamlet is 119 and Pasapuat Hamlet is 530 people (SCB, 2015). The occupation of residents in those three hamlets are mostly on the land i.e farming and cattleman. The location of hamlets is bordered by two big straits, that is the Sipora Strait and the Mentawai Strait and also on the track of collision of tectonic plates (Eurasia plate and India-Australia plate) so vulnerable to wind, waves and Tsunami. Some residents still doing fishing with traditional equipment on nearby coastal waters (less than $200 \mathrm{~m}$ ), especially in Mapinang Hamlet. Pasapuat Hamlet is the worst location due to the Tsunami at year 2010 in the entire of The East Coast at North Pagai Island. The distance of fresh water for consumption is about $10 \mathrm{~m}$ from the shoreline. 
The Matobe Village (Polaga Hamlet, Matobe Tunang Hamlet and Mangaungau Hamlet)

The availability of fresh water's source on the central part of The East Coast is about 1 to $2 \mathrm{~km}$ from the shoreline. Matobe Village has three coastal Hamlets: Polaga Hamlet, Mangaungau Hamlet and Matobe Tunang Hamlet. Due to the considerable freshwater distance, local people use pipes for the distribution of water from hills or mountains. The occupation of the residents such as fishermen, local government employees, farmers and cattleman. The total population of this village is 641 people (SCB, 2015). There are several small fishery businesses owned by individuals or groups of fishermen. The main commodities are grouper and lobster.

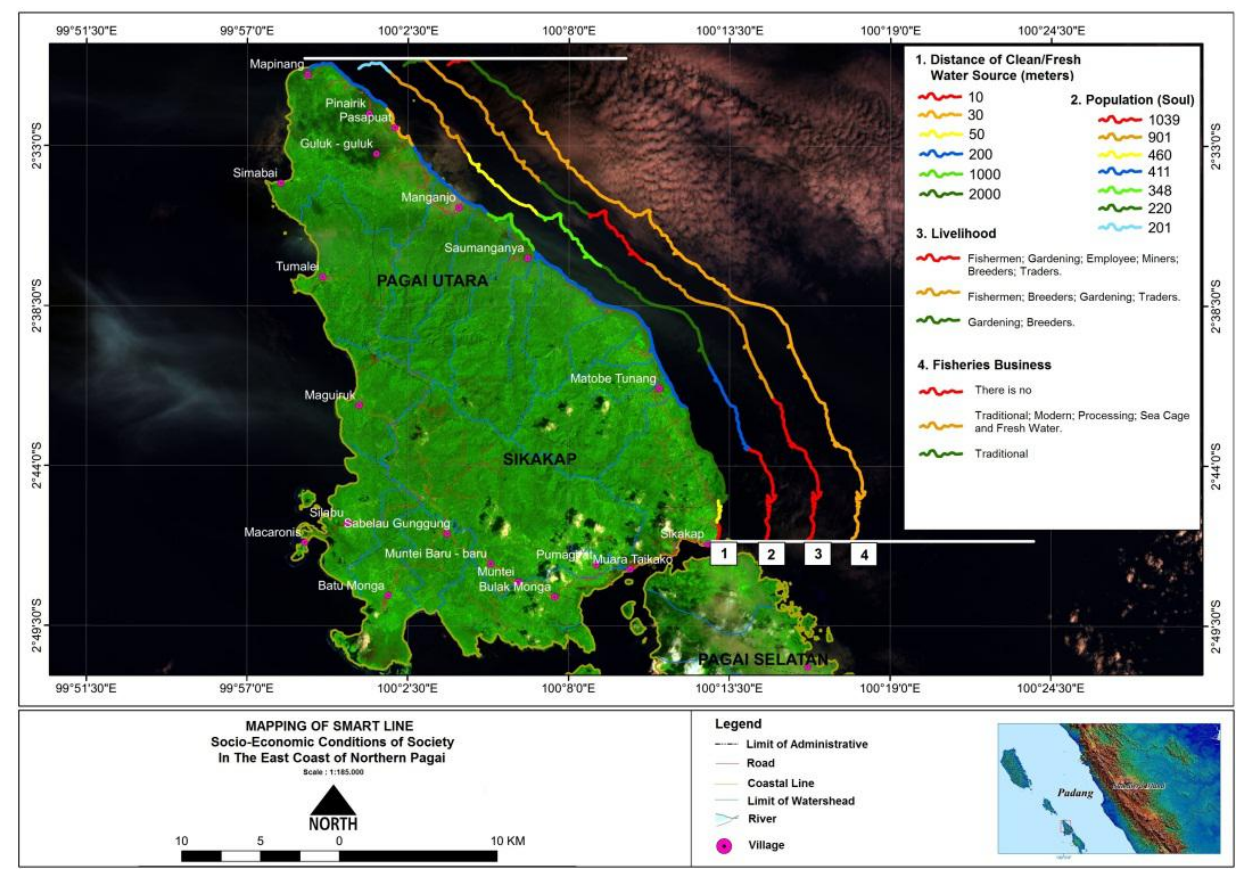

Figure 5. Smartline Map for Socio-Economic Aspect.

\section{Conclusion}

The result of physical aspect shows that The East Coast of North Pagai Island has 2 (two) vulnerability categories that is very high and high. On the north and middle side of the eastern coastal, the vulnerabilty index of The Saumangaya and The Matobe Village is high and very high (CVI 3,2 - 3,5 and 4.2) while in the southern coastal, The Sikakap Village is very high vulnerability (CVI 4.2) especially in abration. Coastal materials are generally divided into 2 (two) types, that is white sand on the northern and some in middle side, while black mud sand on the some of middle to southern side. The coastal slope ranges from $0.3^{\circ}$ to $1.1^{\circ}$. Narrow and sloping beaches are commonly found in Polaga Hamlet and Pasapuat Hamlet. The longest shoreline is in Saumangaya Village. Based on the socio-economic aspect, The Sikakap Village is more advanced but contrary more vulnerable to disaster in terms of population density and complex activities. The condition of some narrow beaches, subduction plate, open beach, black mud sand and the dense population make The East Coast prone to Tsunami, abration and flooding. The North Pagai Island is a vulnerable island from physical and socio-economic aspects.

\section{References}

Adger WN, Brooks N, Bentham G, Agnew M, Eriksen S. (2004). New indicators of vulnerability and adaptive capacity. Tyndall Centre for Climate Change Research (Technical Report 7: Final Project Report). 122p. 
Briggs, R.W., Sieh, K., Meltzner, A.J., Natawidjaja, D., Galetzka, J., Suwargadi, B., Hsu, Y.-j, Simons, M., Hananto, N., Suprihanto, I., Prayudi, D., Avouac, J.-P., Prawirodirdjo, L., Bock, Y., (2006). Deformation and slip along the Sunda mega-thrust in The Great 2005 Nias-Simeulue Earthquake. Science 311, 1897-1901.

Budhitrisna, T. and S. Andi Mangga. (1990). Geology of the Pagai and Sipora quadrangle, Sumatra. Research Center and Development of Geology. Bandung. pp:1-21.

Dolan A., and Walker I.J. (2004). Understanding vulnerability of coastal communities to climate change related risks. J Coast Res Spec Iss Brasilia, 39.

Doukakis, E. (2005). Coastal Vulnerability and Risk Parameters. European Water 11/12: 3-7.

ENVI. Exelis Visual Information Solution Classic Help. (2008). ENVI Classic Tutorial. Classfication Method.

Herdiana Mutmainah, Rizki Anggoro Adi, Aprizon Putra, Try Altanto, Ulung Jantama Wisha, Whisnu Arya Gumilang, Ilham Adnan, Mugiyanto, Prima Sahputra and Ilham Tanjung. Final Report of Coastal Resources and Vulnerability Research at North Pagai Island Year 2016. (2016). Research Institute of Coastal Resources and Vulnerability (RICRV, MMAF). Padang. West Sumatera.

Hill, E.M., Borrero, J.C., Huang, Z., Qiu, Q., Banerjee, P., Natawidjaja, D.H., Elosegui, P., Fritz, H.M., Suwargadi, B.W., Pranantyo, I.R., Li, L., Macpherson, K.A., Skanavis, V., Synolakis, C.E., Sieh, K., (2012). The 2010 MW 7.8 Mentawai Earthquake: Very Shallow Source of A Rare Tsunami Earthquake Determined from Tsunami Field Survey and Near-Field GPS Data. J. Geophys. Res. 117, B06402. http://dx.doi.org/10.1029/2012JB009159.

IPCC. (2001). Summary for Policymakers. Climate Change 2001: Synthesis Report. An Assessment of the Intergovernmental Panel on Climate Change. http://www.ipcc.ch/pdf/climate-changes-2001/ synthesis-spm/synthesis-spm-en.pdf.

Konca, A.O., Avouac, J.-P., Sladen, A., Meltzner, A.J., Sieh, K., Fang, P., Li, Z., Galetzka, J., Genrich, J., Chlieh, M., Natawidjaja, D.H., Bock, Y., Fielding, E.J., Ji, C., Helmberger, D.V., (2008). Partial Rupture of A Locked Patch of The Sumatra Megathrust During The 2007. Earthquake sequence. Nature 456, 631 - 635. http://dx.doi.org/10.1038/nature.07572.

Linds de Baros FM and Muehe Dieter. (2011). The smartline approach to coastal vulnerability and social risk assesment applied to a segment of the east coast of Rio de Janeiro State, Brazil. CSpringer Science+Business Media B.V.2011.

Natawidjaja, D.H. (2011). Geomagz. 2011. Vol. I No.4. Desember 2011. ISSN:2088-7906. Geology Agency of Ministry of Energy and Minerale Resources of Republic Indonesia. Bandung. p.30:112.

Pagai Sipora Sheet. (1990). PPPG. Ministry of Energy and Minerale Resources of Republic Indonesia.

President Regulation of Republic Indonesia No.131 Year 2015 about Decision of Under Developed Area in Indonesia Year 2015-2019. http://jdih.bpk.go.id/wp-content/uploads/2012/03/Perpres-Nomor-131Tahun-2015.pdf. Accesed on 7 March 2016.

Ramieri, E., Hartley, A., Barbanti, A., Santos, F.D., Laihonen, P., Marinova, N. and Santini, M. (2011). Methods for Assessing Coastal Vulnerability to Climate Change. ETCCCA Background Paper. European Environment Agency, Copenhagen.

RBI Map Sheet Number 0714. Scale 1:250.000. (1986). Bakosurtanal.

Sharples C, Attwater C, Carlery J. (2008). Three pass approach to coastal risk assessment. Paper presented at National Conference Responding to Sea Level Rise". Institute of Public Works Engineering Australia, Coffs Harbour, New South Wales, August 2008. http://www.ipwea.org/sustainability/librarydocuments/library/conferencepapers.

Sharples C. (2006). Indicative mapping of Tasmanian coastal geomorphic vulnerability to sea level rise using GIS line map of coastal geomorphic attributes. In: Woodroffe CD, Bruce EM, Puotinen M (eds) Wollongong Paperson Maritime Policy. No.16 pp: 235-247.

Shearer, P., Bürgmann, R., (2010). Lessons learned from the 2004 Sumatra Andaman megathrust rupture. Annu. Rev. Earth Planet. Sci. 38, 103-131. http://dx.doi.org/10.1146/annurev-earth-040809-152537 
Small C, and Nicholls RJ. (2003). A global analysis of human settlement in coastal zones. J Coast Res, Fla 19(3):584-599.

Statistic Center Beaureu (SCB) of Mentawai Islands Regency. (2016). Mentawai Islands in Number 2016. Tuapeijat. The Mentawai Islands Regency.

Statistic Center Beaureu (SCB) of North Pagai District. (2015). North Pagai District in Number 2015. The Saumangaya. The North Pagai District.

Statistic Center Beaureu (SCB) of Sikakap District. (2015). Sikakap District in Number 2015. The Sikakap. The Sikakap District.

Supporting Document for the Preparation of Zoning Plan of Coastal and Small Islands (SDPZPCSI) of West Sumatera Province in Mentawai Islands Regency Year 2015. (2015). Central Management of Coastal and Marine Resources, Ministry of Marine Affairs and Fisheries (CMCMR, MMAF). Padang. West Sumatera.

The CGIAR Consortium for Spatial Information. (2016). Accesed $3^{\text {rd }}$ November 2016 from http:// srtm.csi.cgiar.org/SELECTION/listImages.asp.

USGS Science for a Changing World. (2016). Accesed $3^{\text {rd }}$ November 2016 from: http://earthexplorer.usgs.gov/.

Wahyudi, T. Hariyanto, and Suntoyo. (2009). Analysis of Coastal Vulnerability at North Java's Coastal. Prossiding. National Seminar of Theory and Application. 2009. Surabaya. Semarang Technology Institut. 